\title{
Identification and characterization of allergens in spices by mass spectrometry
}

\author{
Marlene Hummel, Tina Wigger, Jens Brockmeyer \\ From 5th International Symposium on Molecular Allergology (ISMA 2013) \\ Vienna, Austria. 6-7 December 2013
}

\section{Background}

One of the major sources of hidden allergens in food is the use of spices that contain undeclared allergenic ingredients. Sesame and mustard are highly relevant in this context, as both seeds are frequently used in a variety of spices and can elicit severe allergenic reactions. Major allergens of mustard and sesame belong to the $2 \mathrm{~S}$-albumin family of seed storage proteins. 2S-albumins are members of the prolamin superfamily and are widely distributed in seeds and tree nuts. $2 \mathrm{~S}$-albumins are synthesized as a single precursor protein with about 13 $\mathrm{kDa}$ size that is subjected to extensive posttranslational proteolytic processing. The mature $2 \mathrm{~S}$ albumins are composed of two subunits of approximately 9-10 kDa and 3-4 $\mathrm{kDa}$ size, respectively, which are linked by disulfide bridges. The $2 \mathrm{~S}$ albumins are encoded by a multigene family possibly leading to numerous isoforms that may show considerable differences in their structures and allergenicity. The precise number, amount and characteristics of $2 \mathrm{~S}$ albumin isoforms present in mustard and sesame however still remain unclear. One characteristic modification found is the $\mathrm{C}$-terminal clipping of the small subunit that has been exemplarily described for Ses i 1 [1].

\section{Method}

To analyze structural characteristics of $2 \mathrm{~S}$ albumin isoforms in detail, mustard and sesame seeds were ground to a fine powder in a nitrogen-cooled mill and defatted by pentane extraction. The dried powder was suspended in different buffers for 2 hours under continuous shaking. The supernatant was subjected to gel permeation chromatography on a preparative Superdex 200 column and equilibrated in $0.1 \mathrm{mM}$ Tris- $\mathrm{HCl}(\mathrm{pH} 8.0)$. Gel permeation fractions were applied to either a protein (Accucore

Westfaelische Wilhelms-Universitaet, Institute of Food Chemistry, Muenster, Germany

(c) 2014 Hummel et al; licensee BioMed Central Ltd. This is an Open Access article distributed under the terms of the Creative Commons Attribution License (http://creativecommons.org/licenses/by/2.0), which permits unrestricted use, distribution, and reproduction in any medium, provided the original work is properly cited. The Creative Commons Public Domain Dedication waiver (http://creativecommons.org/publicdomain/zero/1.0/) applies to the data made available in this article, unless otherwise stated.
150-C4) or - after tryptic digestion - a peptide (Accucore 150-C18) column and analyzed by HRMS (high resolution mass spectrometry).

\section{Results}

The major 2S-albumins of mustard (Sin a 1, Sin a 2) and sesame (Ses i 1, Ses i 2) could be purified by gel permeation chromatography and characterized using a combination of bottom-up and top-down proteomics. Using this appraoch, novel isoforms of $2 \mathrm{~S}$ albumins in mustard could be characterized. In addition, unknown C-terminal clipping of the large subunit of $2 \mathrm{~S}$ albumins in sesame was observed.

\section{Published: 17 March 2014}

\section{Reference}

1. Moreno FJ: Biochim Biophys Acta. 2005, 1752:142-53.

doi:10.1186/2045-7022-4-S2-P1

Cite this article as: Hummel et al.: Identification and characterization of allergens in spices by mass spectrometry. Clinical and Translational Allergy 2014 4(Suppl 2):P1. and take full advantage of:

- Convenient online submission

- Thorough peer review

- No space constraints or color figure charges

- Immediate publication on acceptance

- Inclusion in PubMed, CAS, Scopus and Google Scholar

- Research which is freely available for redistribution 